Leuven Centre

for Global

Governance Studies

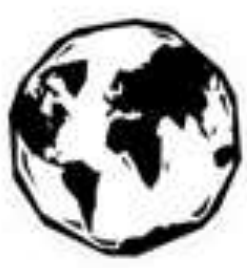

Institute for International Law

Working Paper No. 153 - March 2015

\title{
Space Debris Remediation, its REGULATION AND THE ROLE OF EUROPE
}

Jan Wouters

Philip De Man

Rik Hansen

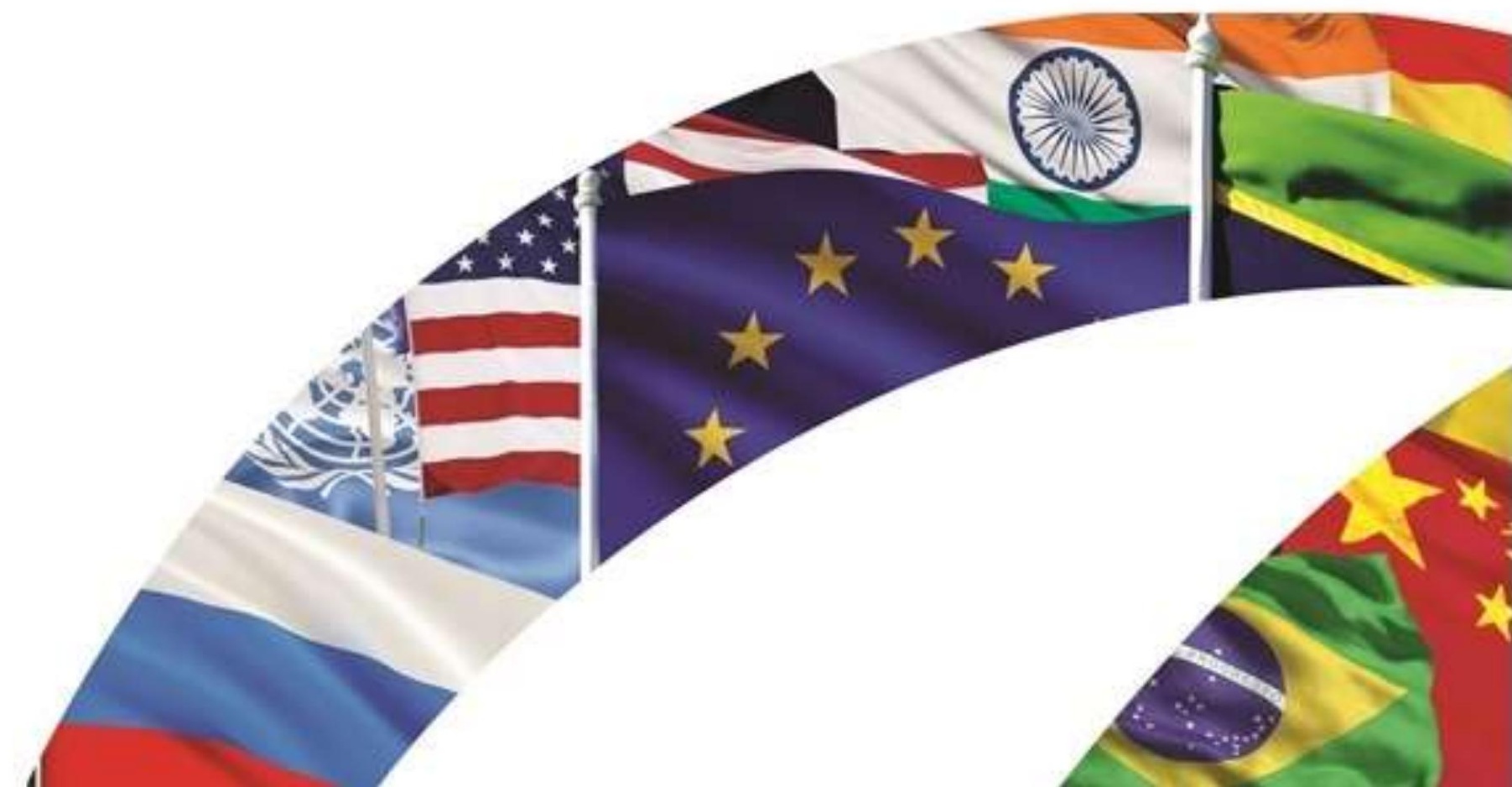


Electronic copy available at: http://ssrn.com/abstract=2589429 


\title{
Space Debris Remediation, its Regulation AND THE ROLE OF EUROPE
}

\author{
Jan Wouters \\ Philip De Man \\ Rik Hansen
}

\begin{abstract}
Ever since the launch of the first space object, discarded bits and pieces ranging from disused payloads and spent upper stages to single bolts and tiny flakes of paint have been cluttering outer space, making valuable and widely used orbits and trajectories to and from Earth increasingly unsafe for future use. The response of the international community to this immediate threat to the sustainable use of outer space has been slow and haphazard, and remains limited to non-binding guidelines and technical recommendations for space debris mitigation. Recent events such as the 2007 Chinese ASAT test and the 2009 collision between an active American and an in-operational Russian communications satellite demonstrate that more needs to be done in order to develop a strong international regime on active debris remediation. Given the complexities of these issues and the lengthy nature of international negotiations, one should not expect a comprehensive legal regime for space debris mitigation and remediation to materialize any time soon. As it is in the own interest of its users to preserve outer space for future exploration and use, the regulation of debris mitigation by space agencies may well prove a valuable alternative as a starting point for binding remediation rules. Since new international initiatives in this respect are lacking, the present article looks at the various space actors in Europe, and at the role some of them may play in developing global rules of space debris remediation.
\end{abstract}

\section{KEYWORDS}

International Space Law; Space Debris; Space Debris Remediation; European Union; European Space Agency; European Space Agencies; European Space Policy; Lisbon Treaty; Art. 189 TFEU

\section{AUTHORS}

Jan Wouters is Jean Monnet Chair ad personam EU and Global Governance, Full Professor of International Law and International Organizations and Director of the Leuven Centre for Global Governance Studies and the Institute for International Law (KU Leuven).

Philip De Man is Project Manager at the Leuven Centre for Global Governance Studies (KU Leuven).

Rik Hansen is Doctoral Researcher at the Leuven Centre for Global Governance Studies and the Institute for International Law (KU Leuven).

\section{ADDRESS FOR CORRESPONDENCE}

Jan.Wouters@ggs.kuleuven.be

Philip.DeMan@law.kuleuven.be

Rik.Hansen@ggs.kuleuven.be

(C) 2015 by Jan Wouters, Philip De Man and Rik Hansen. All rights reserved. No portion of this paper may be reproduced without permission of the authors. Working papers are research materials circulated by their authors for purposes of information and critical discussion. They have not necessarily undergone formal peer review. 


\title{
Space Debris Remediation, its Regulation AND THE ROLE OF EUROPE
}

\author{
Jan Wouters \\ Philip De Man \\ Rik Hansen
}

\section{Table of Contents}

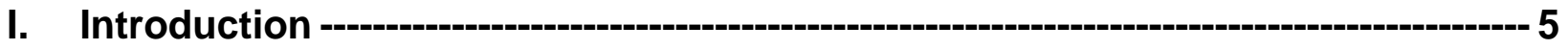

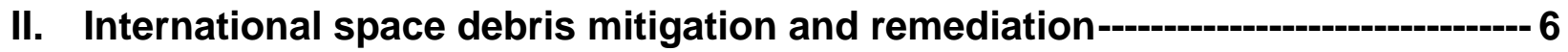

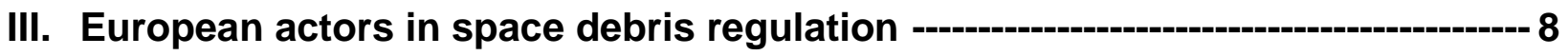

A. The European space agencies -- 9

1. European Space Agency---- 9

2. European space agencies in international initiatives and national implementation----o- 12

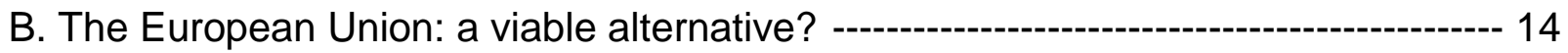

1. EU space competences in the Lisbon Treaty-- 14

2. Respective roles of EU, ESA and their Member States---------- 16

3. EU measures on space debris-------- 17

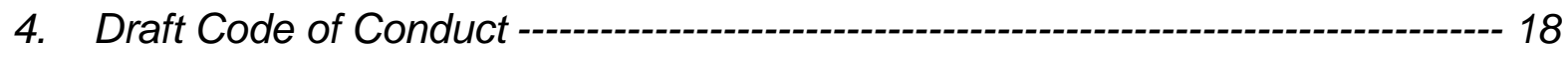

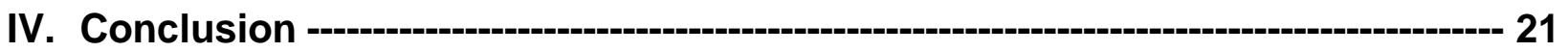




\section{INTRODUCTION}

It is generally accepted that the increasing presence of space debris in such valuable areas of outer space as the geostationary region and low Earth orbit poses one of the greatest practical threats to the continued modern exploration and use of outer space. ${ }^{1}$ Ever since the launch of the first space object, discarded bits and pieces ranging from disused payloads and spent upper stages to single bolts and tiny flakes of paint have been cluttering outer space, making valuable and widely used orbits and trajectories to and from Earth increasingly unsafe for future use. Nevertheless, many questions on the legal regime of space debris have yet to be settled conclusively, including how to adequately define the concept in international law and the legal basis, if any, for the obligation to avoid the additional creation (mitigate) and actively remove (remediate) particularly hazardous pieces of debris.

Currently, international space debris rules are only laid down in non-binding guidelines and technical recommendations aimed at debris mitigation, without addressing the far more costly endeavour and legally intricate matter of debris remediation. By itself, however, space debris mitigation may well be insufficient to ensure long-term sustainability of space activities, for two reasons. First, reducing the creation of space debris to zero is likely not achievable in the short to medium turn. For the foreseeable future, space activities are likely to entail at least some creation of debris. Second, even excluding the creation of additional space debris, the existing debris in certain orbital regions has reached such levels that collisions between fragments of debris cause a multiplication of the number of fragments in orbit (although evidently their total mass would remain constant). This effect of debris generating more debris can, under certain conditions, become a cascade. This is known as the Kessler syndrome, after the NASA scientist who predicted its occurrence.

Given the complexities of the legal issues involved in debris removal and the lengthy nature of international negotiations, one should not expect the limited set of non-binding rules adopted so far to be complemented by a comprehensive regime for space debris mitigation and remediation any time soon (section II). As it is in the own interest of the users of outer space to avoid the creation of additional space clutter and to remove the most hazardous existing pieces of space debris so as to preserve outer space for future exploration and use, the regulation of debris mitigation by space agencies may well prove a useful alternative as a starting point for binding remediation rules. Since new international initiatives in this respect are lacking, the present article looks at the various space actors in Europe, in particular the European Space Agency (ESA) and the European Union (EU or Union), and at the role they may play in developing global rules of space debris remediation (section III).

\footnotetext{
${ }^{1}$ L. Perek, "Traffic rules for outer space", 25 Proc. Coll. L. Outer Space 1982, p. 40; G. Leinberg, "Orbital space debris", 4 J.L. \& Tech. 1989, p. 93; M. Benkö and K.-U. Schrogl, "The UN Committee on the Peaceful Uses of Outer Space: adoption of the Resolution on Enhancing Registration Practice and of the UNCOPUOS Space Debris Mitigation Guidelines", 57 Zeit. Luft- \& Weltraumr. 2008, p. 344.
} 


\section{INTERNATIONAL SPACE DEBRIS MITIGATION AND REMEDIATION}

Lack of progress in establishing strong international rules for space debris remediation can be attributed to the difficulties in harmoniously incorporating the concept of space debris in a legal framework that has been developed and applied for several decades without directly addressing the notion. Difficulties persist mainly because there is no consensus on whether the United Nations (UN) space treaties, in particular the 1967 Outer Space Treaty (OST), the 1972 Liability Convention (LIAB) and the 1975 Registration Convention (REG), are directly applicable to space debris. ${ }^{2}$ The answer to this question largely depends on whether the steppingstone notion of 'space object' in these conventions should include non-functional objects, or if it is limited to functional items only.

Even if the UN treaties apply to space debris in general, the particular relevance of specific provisions, including Article I OST on the free use of outer space and Article IX OST on harmful interference and the space environment, remains highly uncertain. It is also unclear whether Article VIII OST opposes any incursion by other states to de-orbit satellites that are no longer used by the registering state. And it is uncertain to what extent the UN space treaties can effectively be applied to protect against space debris from an environmental perspective.

The international space law regime is predicated on the fundamental principle that outer space, including the Moon and other celestial bodies, is free for exploration and use by all states, and that such activities shall be carried out for the benefit and in the interest of all states (Art. I OST). Although it is unlikely that a binding obligation of mitigation and active removal of all types of space debris could be derived from a principle so vague and general in its formulation, the foundational nature of the provision is revelatory of an underlying goal that must inform the interpretation of other provisions in the international space law regime and, as such, may reveal an implied obligation to limit the debris population in outer space. ${ }^{3}$

One of the most important provisions in this regard is Article IX OST, which requires all users of outer space to conduct all their activities of exploration and use with due regard to the corresponding interests of other users, both present and future, and to undertake 'appropriate international consultations' with others if potentially harmful interference is likely to arise as a result of their activities. The provision has an environmental component as well, in that it requires states to conduct studies to avoid the harmful contamination of outer space and the celestial bodies therein. The provision is strengthened in the 1979 Moon Agreement (MA), which, though hampered by a comparatively small number of ratifications and applicable only to activities on the Moon and other celestial bodies, requires all states parties to "prevent the disruption of the existing balance" of the environment of celestial bodies (Art. $7 \mathrm{MA}$ ).

\footnotetext{
${ }^{2}$ See, for example, R. Müller, "The scope of validity and effectiveness of environmental-related norms in outer space law", in T.L. Zwaan, W.W.C. De Vries, P.H. Tuinder and I.I. Kuskuvelis (eds.), Space law: views of the future, Deventer, Kluwer Law and Taxation, 1988, p. 140; N. Jasentuliyana, "Space debris and international law" $26 \mathrm{~J}$. Space L. 1998, p. 140-145.

${ }^{3}$ On the interpretative value of Art. I OST, see: C. Q. Christol, Space Law. Past, Present, and Future, Kluwer Law and Taxation, Deventer, 1991, p. 70.
} 
The vast majority of existing space debris has been created unintentionally as an - for all practical purposes - unavoidable by-product of legitimate activities in space. It can be argued that its creation does not contravene Articles I and IX OST, for their existence in space could arguably be avoided only by proscribing the lawful forms of exploration and use that brought them about in the first place. However, the same does not necessarily hold for activities entailing the wanton creation of space debris in an uncontrolled manner. As an example, one may refer to the notorious ASAT test conducted by China on 11 January 2007. The intentional destruction of a Chinese weather satellite resulted in the single greatest act of man-made space debris creation, most of which is still in orbit around Earth today and will be for many years to come. Despite wide denunciation of the unilateral act as an unnecessary complication of the space clutter conundrum, ${ }^{4}$ it has not been condemned as a violation of international (space) law. ${ }^{5}$

In light of the elementary uncertainties in legal interpretation and the vague formulation of the existing space law principles cited earlier, it should come as no surprise that a coordinated and comprehensive response to the space debris conundrum is still sorely lacking. What little initiatives have been undertaken in this respect focus almost solely on the dissemination of best practices and technical lessons learned in order to persuade states and other users of outer space to take the necessary precautions to avoid unnecessarily adding clutter to the existing amount of space debris.

The most prominent set of rules in this respect can be traced to the adoption in October 2002 of the Space Debris Mitigation Guidelines by the Inter-Agency Space Debris Coordination Committee (IADC). ${ }^{6}$ The document offers a set of non-binding guidelines for space agencies, "with an emphasis on cost effectiveness, that can be considered during planning and design of spacecraft and launch vehicles in order to minimise or eliminate generation of debris during operations". ${ }^{7}$ The IADC is an international forum of governmental bodies for the coordination of activities related to the issues of man-made and natural debris in space. Its membership comprises ESA, the four main national European space agencies and their Chinese, Indian, Japanese, Russian, American and Ukrainian partners.

The work of the IADC greatly influenced the negotiations in the Scientific and Technical Subcommittee (STSC) of the United Nations Committee on the Peaceful Uses of Outer Space (UN COPUOS), which adopted a nearly identical version of the Guidelines in $2007 .{ }^{8}$ The close degree of cooperation between IADC and the UN COPUOS STSC also shows in the submission of annual reports by the IADC members to the Subcommittee on their implementation of space debris mitigation activities. The UN COPUOS debris mitigation

\footnotetext{
${ }^{4}$ Compare the last in-space ASAT-test before the 2007 incident, conducted by the United States in 1985, which resulted in a smaller number of space debris particles, all of which had been deorbited by 2008.

5 See "Britain concerned by Chinese satellite shoot-down", Space War, 19 January 2007, available at http://www.spacewar.com/reports/Britain Concerned By Chinese Satellite Shoot Down 999.html (accessed on 24 February 2015).

${ }_{7}^{6}$ Available at http://www.iadc-online.org/index.cgi?item=docs pub (accessed on 23 February 2015).

${ }^{7}$ Foreword of the Guidelines.

${ }^{8}$ Annex to the Report of the UN COPUOS to the 62nd session of the UNGA, UN Doc. A/62/20.
} 
guidelines were endorsed a year later by the UN General Assembly (UNGA). ${ }^{9}$ While these rules are henceforth globally applicable, they remain legally non-binding. ${ }^{10}$

On a more technical level, international space debris mitigation standards have been developed by the International Organization for Standardization (ISO), through its Orbital Debris Coordination Working Group (ODCWG) within Subcommittee 14 of Technical Committee 20 (TC20/SC14). ${ }^{11}$ The main top-level standard on space debris mitigations requirements was adopted in 2010 and has been revised in 2011. ${ }^{12}$ The standard "defines the primary space debris mitigation requirements applicable to all elements of unmanned systems launched into, or passing through, near-Earth space" and is designed to "reduce the growth of space debris by ensuring that spacecraft and launch vehicle orbital stages are designed, operated and disposed of in a manner that prevents them from generating debris throughout their orbital lifetime". ${ }^{13}$ It is accompanied by a series of lower implementation standards that ensure compliance.

Despite these advances made at the international level, recent events such as the Chinese ASAT test and the 2009 collision between an active American and an in-operational Russian communications satellite demonstrate that the existing international space debris mitigation regime leaves much to be desired, in large part due to its technical and non-binding nature. Moreover, no efforts whatsoever have been undertaken to oblige states and space agencies to engage in active retrieval or removal of hazardous inactive space objects in an effort to curb further increases in space junk. When considering the regulation of such cases of debris remediation, the above problems relating to mitigation are further compounded by legal issues of ownership and non-interference, which, after all, work both ways. Indeed, even if nonfunctional pieces of space debris should be considered space objects, being property of the registering state and activating responsibility in case of damages, the question remains whether a state may actively engage in the removal of another state's space junk without interfering and violating the latter's property rights.

\section{EUROPEAN ACTORS IN SPACE DEBRIS REGULATION}

On 13 November 1986, an Ariane-1 H-10 upper-stage booster in a sun-synchronous orbit with a mean altitude of 818 kilometers exploded, resulting in an estimated total of 488 traceable objects of space debris. ${ }^{14}$ Some of the fragments that resulted from this explosion later collided with the French military reconnaissance satellite Cerise on 24 July 1996, which was likewise positioned in a Low Earth Orbit (LEO) synchronized with the Sun. ${ }^{15}$ Tearing off more than half of Cerise's stabilization boom, the collision left the French satellite severely unbalanced, while

\footnotetext{
${ }^{9}$ UNGA Resolution A/RES/62/217 of 1 February 2008, para. 26.

10 See UN Doc. A/62/20, p. 48: "Member States and international organizations should voluntarily take measures, through national mechanisms or through their own applicable mechanisms, to ensure that these guidelines are implemented, to the greatest extent feasible, through space debris mitigation practices and procedures".

11 See the resolution establishing the ODCWG, adopted by T20/SC14 in May 2003.

12 ISO 24113:2010 and ISO 24113:2011 on Space Systems - Space Debris Mitigation Requirements.

${ }_{14}^{13}$ See http://www.iso.org/iso/catalogue detail.htm?csnumber=42034 (accessed on 23 February 2015).

$14 \mathrm{H}$. Klinkrad et al., "Space debris activities in Europe", Proceedings of the Fourth European Conference on Space Debris, Darmstadt, 18-20 April 2005.

${ }^{15}$ H. Klinkrad, Space debris: models and risk analysis, Berlin, Springer, 2006, 2.
} 
adding yet more fragments to the ever-expanding population of space debris. ${ }^{16}$ Not only was the event the first irrefutable proof that active debris remediation was needed in LEO, it also underscored the particular importance of involving all relevant European actors in cleaning up the cluttered space environment.

Nearly 30 years later, it may come as a surprise that none of the European players in space have taken strong regulatory action on space debris remediation. To be sure, they have not remained completely idle on the space debris front altogether. ESA and its member states in particular have undertaken numerous initiatives over the past decades that address the space debris conundrum. As with most global measures, however, these regional initiatives have remained focused on mitigation rather than remediation, for reasons of economy and policy. Nevertheless, from a legal perspective there is no fundamental difference between the promulgation of mitigation measures and remediation rules that would preclude the regulation of active debris removal by the same actors. Hence, the development and implementation of the manifold rules on debris mitigation may serve as guidance for laying out the route to debris remediation regulation by European players in space.

In particular, the history of the European involvement in the regulation of debris mitigation reveals two parallel paths that may prove instrumental for debris remediation: building on the efforts of the European space agencies in debris mitigation (subsection A) and using the newly acquired space policy competences of the EU in the Treaty of Lisbon to adopt a comprehensive regulatory framework on space debris (subsection $B$ ).

\section{A. THE EUROPEAN SPACE AGENCIES}

\section{European Space Agency}

The tragic Ariane incident of 1986 marked the start of a systematic and concerted effort of the various space agencies in Europe to comprehensively address the dangers posed by a cluttered space environment. Owing perhaps to one of the chief purposes set out in Article II of its Convention - that of fulfilling a coordinating role in the European space landscape - most of these measures originated with ESA. Within ESA, research activities in all major debris disciplines are coordinated by the Space Debris Office. The Office also coordinates its debris activities with national research efforts of the four national space agencies of ESA/EU member states: France (CNES), Germany (DLR), the United Kingdom (UK Space Agency) and Italy (ASI). Together with ESA, these national agencies form the European Network of Competences on Space Debris (SD NoC). The SD NoC was established in 2008 to replace the European Network of Centres for Space Debris, which had succeeded the Space Debris Advisory Group (SDAG) of European experts in 1999. The SDAG was established in 1987 to coordinate research activities on space debris between ESA and the national space agencies.

16 T. Reichhardt, "Satellite smashers", Air \& Space Magazine, March 2008, available at http://www.airspacemag.com/space/satellite-smashers-25098285/ (accessed on 23 February 2015). 
The preparations for regulatory action on space debris took off in 1986 when ESA Director General Reimar Lüst created an internal Space Debris Working Group to assess all aspects of the convoluted space debris problem. Little over a year later, the working group published its findings in a report, which gained the formal approval of the ESA Council in 1989. ${ }^{17}$ The report prompted the adoption of a Resolution on the Agency's policy vis-à-vis the space debris issue ${ }^{18}$ and a document outlining ESA Activities on Space Debris ${ }^{19}$, in which the Council defined the main objectives of the Agency regarding future space debris initiatives. Couched in general terms that nevertheless mainly speak to mitigation rather than remediation, the primary goal of these activities is to 'minimize the creation of space debris to ensure safe access to space, and to reduce the risk for manned and unmanned space flight'. Other objectives include the reduction of the risk on ground due to re-entries of space objects and the risk for geostationary satellites; examine the legal aspects of space debris; and acquire, through own facilities and in cooperation with other space agencies, the data on space debris necessary to assess the extent of the problem and its consequences. ${ }^{20}$

Ten years later, ESA promulgated its Space Debris Mitigation Handbook. ${ }^{21}$ The Handbook, last updated in 2002, is a self-standing document developed by ESA providing technical information in support of debris mitigation standards of European agencies, which are, in turn, compiled in the European Space Debris Safety and Mitigation Standard. ${ }^{22}$ The Standard was developed in 2003 by a special European Debris Mitigation Standard Working Group, so as to represent fundamental safety and mitigation requirements and recommendations related to space debris. ${ }^{23}$ Together, both documents define the Agency's policies, implementation concepts, and technical recommendations concerning space debris mitigation and collision risk reduction for any mission under ESA control.

The 2000 ESA Council Resolution for a European Policy on Protection of the Space Environment from Debris confirms the main objectives of the aforementioned 1989 resolution in terms of debris mitigation, without, however, expanding their scope to active remediation. ${ }^{24}$ The resolution calls for ESA and its member states to further intensify their efforts to coordinate their respective programmes on space debris, at the regional and global level, through cooperation with such institutions as the UN COPUOS, the IADC, and the International Telecommunications Union (ITU). Furthermore, the resolution invites ESA member states to take all necessary measures to study the legal aspects of the space debris problem, in cooperation with, among

${ }^{17}$ ESA Space Debris Working Group, Space debris: a report of the ESA Space Debris Working Group, ESA SP1109, November 1988.

${ }_{19}^{18}$ ESA Council Resolution of 29 June 1989, ESA/C/LXXXVII/Res.3 (final).

${ }^{19} \mathrm{ESA} / \mathrm{C}(89) 24 / \mathrm{rev} .1$.

${ }^{20}$ M. Flury, "Space debris activities in Europe", Proceedings of the Third European Conference on Space Debris, Darmstadt, 19-21 March 2001.

${ }^{21}$ Referenced on http://www.esa.int/About Us/ECSL European Centre for Space Law/Space Debris3 (accessed on 23 February 2015).

${ }^{22}$ On these ESA documents, see H. Klinkrad (ed.), The ESA Space Debris Mitigation Handbook, ESOC, Darmstadt, 1999; H. Klinkrad et al. "The ESA Space Debris Mitigation Handbook 2002", 34 Advances in Space Research 2004, 1251-1259.

${ }^{23}$ See F. Alby et al., "The European Space Debris Safety and Mitigation Standard", 34 Advances in Space Research, 2004, 1260-1263.

${ }^{24}$ ESA Council Resolution of 20 December 2000, ESA/C/CXLIX/Res.6, reprinted in K.-H. Böckstiegel, M. Benkö and S. Hobe (eds.), Space law: basic legal documents, Dordrecht, Martinus Nijhoff, 1990, B.III.13. 
others, the International Institute of Space Law (IISL) and the European Centre for Space Law (ECSL).

While the text of the resolution omits any explicit reference to the EU, the call on ESA member states to study the possibility of regulatory action on space debris obviously appealed to most EU member states as well, given the largely overlapping membership of both organizations (see infra). As such, the French Centre Nationale d'Etudes Spatiales had already taken the initiative to adopt debris regulation following the collision of the Ariane rocket with its own reconnaissance satellite in 1996. Determined to prevent future collisions, the CNES elaborated a collection of standards, methods and procedures on space debris from 1997 until its adoption in $1999 .{ }^{25}$ Along with the ESA Handbook of the same year, the 1999 CNES Standards Collection served as the main basis for the draft European Space Debris Safety and Mitigation Standard.

The above efforts ultimately culminated in a European Code of Conduct for Space Debris Mitigation, adopted in 2004. ${ }^{26}$ The Code was "developed co-operatively amongst responsible space agencies in Europe to identify those practices that will serve to minimize the impact of space operations on the orbital environment to be encountered by future space systems". ${ }^{27}$ Its primary objectives are the prevention of on-orbit break-ups and collisions; the removal and subsequent disposal of spacecraft and orbital stages from the useful densely populated orbit regions at the end of their operational life; and the limitation of objects released during normal operations. $^{28}$ The Code of Conduct was formally approved by the Director General of ESA and the directors of the national space agencies of France, Germany, the UK and Italy. Although its application is voluntary, the Code can be given binding effect by means of legal instruments between the contracting parties. ${ }^{29}$

While the voluntary nature of the 2004 Code of Conduct has undoubtedly facilitated its adoption, it has commensurately impeded its enforcement. Likewise, the imprecision of the Code's provisions has hindered their direct implementation by the addressees of the obligations. ESA Director General Jean-Jacques Dordain, therefore, insisted on a clarification of the Code's content and recommended the adoption of a set of implementation standards and requirements. ${ }^{30}$ This resulted in the promulgation by the Agency of the Requirements for Space Debris Mitigation for ESA Projects. ${ }^{31}$ Like all other European measures on space debris identified in this segment, however, these 2008 requirements are tailored to the mitigation of the debris population by curtailing the freedom of operators for future space systems only. Indeed,

${ }^{25}$ Exigences de Sécurité - Debris Spatiaux, Méthode et Procédure, Référentiel Normatif CNES, CNES, Toulouse, 19 April 1999, RNC-CNES-Q-40-512.

${ }_{26}^{26}$ Available at http://www.unoosa.org/pdf/spacelaw/sd/2004-B5-10.pdf (accessed on 23 February 2015).

${ }^{27}$ Foreword of the Code.

28 Introduction of the Code.

${ }^{29}$ Article 2.2 of the Code.

${ }^{30}$ See the Instruction of the ESA Director General on Space Debris Mitigation for Agency Projects of 1 April 2008, ESA/ADMIN/IPOL(2008)2.

Available at http://www.iadconline.org/References/Docu/ESA\%20Requirements\%20for\%20Space\%20Debris\%20Mitigation.pdf (accessed on 23 February 2015). 
the document is to be used as an ESA applicable standard for all procurements of space systems started after its entry into force. It is applicable to the procurement of "new launchers, satellites and inhabited objects" and is directed at the prime contractors of ESA space projects, who should justify any case of non-compliance in writing to the Director General. ${ }^{32}$

\section{European space agencies in international initiatives and national implementation}

The previous subsection described the current body of regional measures intended to mitigate the creation of new fragments of space debris by projects of the space agencies in Europe. However, the adoption and subsequent evolution of the CNES Standards Collection into the 2004 European Code of Conduct for Space Debris Mitigation, directed in turn at operators and contractors of space projects initiated by ESA and the national space agencies of four principal ESA member states, already illustrates the arbitrariness of any categorization of measures as being strictly 'regional'. The intergovernmental nature of ESA as an organization composed of member states, many of whom have national space agencies, and most of which are member states of the EU as well, ipso facto precludes any such compartmentalization. Moreover, at the time they were developing internal debris measures, most space agencies in Europe were also members of various international organizations, bodies and institutions that were negotiating debris mitigation regulation at a global level. This introduces another dimension of crossfertilization between different levels of governance that has characterized the development of debris mitigation measures, and which may ultimately inspire the step up to the promulgation of remediation measures as well.

As such, when producing its guidelines, the IADC based itself on information obtained from such documents as the 1999 CNES Standards and the ESA Space Debris Mitigation Handbook and Standard. ${ }^{33}$ In turn, the 2002 IADC guidelines were an important source of inspiration for the 2004 European Code of Conduct. The five European space agencies also contributed to these negotiations through the IADC, which participated in the proceedings of a Space Debris Working Group of the Scientific and Technical Subcommittee. Further, ESA continues to assist the IADC in its information gathering function by maintaining a re-entry events database for reentry predictions of risk objects. Moreover, delegates from the four national European agencies and ESA are also members of the aforementioned ODCWG. As for ESA, its participation in mitigation standardisation practices is based on its 2008 Requirements document. ISO activities on debris mitigation are also supported by the European Committee on Space Standardization (ECSS), a cooperative effort coordinating the contributions of ESA, national space agencies, and European industry associations for the purpose of developing and maintaining common standards.

The participation of national European space agencies and ESA in the negotiations for the adoption of international debris mitigation guidelines by organizations such as the IADC and the UN has not only infused these global rules with European standards; the close involvement of the European space industry has also facilitated implementation of these international rules at

\footnotetext{
${ }^{32}$ Art. 4.1 of the Requirements.

${ }^{33}$ Foreword of the IADC Guidelines.
} 
the national level. Moreover, the close involvement of the same actors that have drafted the 2004 European Code of Conduct for Space Debris Mitigation, signed by all major European space agencies and concretized into specific ESA requirements, has guaranteed a high level of similarity between recently adopted international and European rules on debris mitigation, further favouring compliance with global rules by member states of ESA and the EU. What follows is that, although the international rules of the IADC and the UN are non-binding, states are starting to implement national space debris mitigation measures consistent with or based on these global guidelines on a voluntary basis. ${ }^{34}$

A number of European states in particular are using the IADC Guidelines and the 2004 Code of Conduct as reference points in their regulatory frameworks established for national space activities. ${ }^{35}$ A recent legislative initiative in this respect was the 2008 French Space Operations Act (SOA), which entered into force on 10 December $2010 .{ }^{36}$ Unlike the Code of Conduct, which is limited to CNES projects, the act is applicable to operators carrying out operations from French territory and to French operators anywhere in the world. Pursuant to the SOA, these operators must demonstrate compliance with associated technical regulations developed by the CNES in 2009 and 2010 in close cooperation with the space industry and the operators themselves, in order to guarantee the safety of persons and property, and the protection of public health and the environment, thereby limiting risks related to space debris (Art. 5 SOA). Although it lacks any direct reference to international debris mitigation standards, the French legal framework for space operations is commonly considered to be fully in line with the UN and IADC guidelines, as well as the ISO top-level standard on debris mitigation. ${ }^{37}$ As such, it presents a formally legally binding recuperation at the national level of non-binding international guidelines. Likewise, Germany is in the process of expanding its national space legislation with a law that will ensure compliance of all German space activities with the UN COPUOS Guidelines. This law will add a regulatory framework to the present policy requiring for each

\footnotetext{
${ }^{34}$ Para. 101 of the 2010 UN COPUOS Report A/65/20. See also the report of the International Interdisciplinary Congress on Space Debris, Towards long-term sustainability of space activities: overcoming the challenges of space debris, UN Doc. A/AC.105/C.1/2011/CRP.14. In this report, it is argued that, "[a]lthough the UN COPUOS/IADC Guidelines are not legally binding, and are at best 'soft law', it is presumed that States will implement them in good faith and as appropriate to their national interests".

${ }^{35}$ See F. Alby, "Implementation of space debris mitigation guidelines at CNES", paper no. IAC-05-B6.3.08 at the 56th International Astronautical Congress (2005) and the presentation of the DLR's U. Wirt, 'UN-Space Debris Mitigation Guidelines: national implementation mechanism' at the 48th session of the Legal Subcommittee of the UN COPUOS (2009).

36 Loi $\mathrm{n}^{\circ} 2008-518$ du 3 juin 2008 relative aux opérations spatiales, available at http://legifrance.gouv.fr/affichTexte.do?cidTexte=JORFTEXT000018931380\&fastPos=9\&fastReqld

$=1846263462 \&$ categorieLien=cid\&oldAction=rechTexte. Pursuant to Art. 5, of this law, technical requirements for authorization have been adopted in Arrêté du 31 mars 2011 relatif à la réglementation technique en application du décret $n^{\circ} 2009-643$ du 9 juin 2009 relatif aux autorisations délivrées en application de la loi $n^{\circ} 2008-518$ du 3 juin 2008 relative aux opérations spatiales, available http://legifrance.gouv.fr/affichTexte.do?cidTexte=JORFTEXT000024095828\&fastPos=5\&fastRegld (accessed on 23 February 2015).

37 Compendium of space debris mitigation standards adopted by States and international organizations, Conference Room Paper submitted by Canada, the Czech Republic and Germany to the 53rd session of UN COPUOS, A/AC.105/C.2/2014/CRP.15, pp. 20-23.
} 
contractor to implement a product assurance programme throughout all project phases in order to minimize the creation of space debris. ${ }^{38}$

\section{B. THE EUROPEAN UNION: A VIABLE ALTERNATIVE?}

Previous sections have shown that a number of international guidelines have come into existence, developed on the basis of national and regional space debris mitigation standards and practices that were in turn developed by national and regional space agencies. These international and regional guidelines are adopted by such bodies as the IADC, SD NoC, and the UN COPUOS - all bodies in which the EU as such does not have a formal role and voice. ${ }^{39}$ Of course, in UN bodies, some coordination between member states occurs at the EU level, but the regulatory history of the rules shows that it is mainly the four national space agencies/EU member states and ESA that take the lead. This section examines what role the EU might take up in the future, notably in view of the progressive unfolding of the space competence conferred to it by the Treaty of Lisbon, its implications for the European space governance landscape and, finally, the highly publicised International Code of Conduct for Space Activities.

\section{EU space competences in the Lisbon Treaty}

For the vast majority of its history in space, the EU has been active in this field without a proper legal basis to do so. To circumvent this apparent lack of a space competence, its space activities, including major undertakings such as the GNSS programmes (Galileo and EGNOS) and Copernicus, were based on other, more general EU competences: first on the research and technological development (RTD) competence conferred to it by the 1986 Single European Act, and later on its transport and Trans-European Networks competences. Whereas this scattered legal basis has proved sufficient for ad-hoc initiatives, it has considerably hampered the EU's ability to act as a coordinating and regulating force in the European space landscape. This reason also accounts at least in part for the EU's lack of initiative on space debris mitigation and remediation. A space competence was first provided for in the unratified Treaty establishing a Constitution for Europe, but did not materialise until the entry into force of the Treaty of Lisbon on 1 December 2009.

Pursuant to Article 4(3) of the Treaty on the Functioning of the European Union (TFEU), the EU now has shared competence on space matters, albeit with the additional proviso that this competence, if exercised, will not result in the EU member states being prevented from exercising theirs. Interpretations of this restriction - which the space competence shares with the EU's RTD competence mentioned in the same article - vary, with a number of EU

38 See the 2010 German Space Strategy, available at http://www.bmwi.de/English/Redaktion/Pdf/spacestrategy, property=pdf,bereich=bmwi2012,sprache=en,rwb=true.pdf (accessed on 10 March 2015).

39 On the increasing role of the EU in UN COPUOS, see J. Wouters and R. Hansen, "The Other Triangle in European Space Governance: The European Union, the European Space Agency and the United Nations" in C. JORGENSON, (ed.), Proceedings of the International Institute of Space Law, Eleven International Publishing, The Hague, 2014, 655-668. 
documents speaking simply of a shared competence ${ }^{40}$, whereas scholars have termed it "a shared competence without pre-emption" 41 or a "parallel competence". ${ }^{42}$ This restriction is echoed in Article 189 TFEU, which expressly excludes any harmonisation by the EU of the laws and regulations of its member states. In an internal information note, the Commission is quick to point out that this restriction is not unique to the space competence or to Article 189 TFEU. ${ }^{43}$

The essence of the new space competence of Article 189 TFEU lies in the enumeration of policy goals that the space competence might serve in its first paragraph, and in a nonexhaustive list of measures that could be employed in its pursuit in the first and second paragraphs. As goals for space activities, Art. 189(1) TFEU cites the promotion of scientific and technical progress, the promotion of industrial competitiveness and the implementation of the EU's policies. While the two former goals are new and substantive, the latter seems aimed at maintaining the pre-Lisbon status quo whereby the Union took an instrumental view of space activities at the service of its general competences. Art. 189(1) TFEU furthermore empowers the $\mathrm{EU}$ - with a formulation that is firmly in the imperative tense - to draw up a European space policy for this purpose. It suggests that in order to achieve these goals, the EU can promote joint initiatives, support research and technological development and coordinate exploration and exploitation efforts in space. Art. 189(2) TFEU adds that these goals can be pursued using "the necessary measures", which can take the form of, but need not be limited to, a European space programme. Yet at the same time, it excludes any harmonisation of national laws. On institutional arrangements, a third paragraph in Article 189 TFEU adds that the EU is to establish "any appropriate relations" with ESA.

Limited though these powers of the EU in the field of space may appear, they nevertheless allow the EU to take regulatory action on space debris issues. First, the formulation of Article 189 TFEU only excludes harmonisation of member state laws and regulations (i.e. binding norms). As such, the EU can still take action in the form of best practices, which may then be taken up in national legislation. ${ }^{44}$ Second, the mandate to coordinate efforts in space exploration and exploitation can arguably be interpreted to include measures to guarantee the sustainability of such activities. Finally, as the blanket competence contained in Article 189(1) TFEU indicates, the issue of space debris can be linked with related issues such as environment and security in order to expand the legal bases to act in terms of debris remediation. In an explanatory note on Article 189 TFEU, the Commission notably cites the possibility of approximation of laws in view of the establishment and functioning of the internal market as contained in Article 114 TFEU. ${ }^{45}$

\footnotetext{
${ }^{40}$ See e.g. Communication from the Commission: "Towards a space strategy for the European Union that benefits its citizens", 11 Apr. 2011, COM(2011) 152 p. 3, p. 11; Information note: Article 189 of the Treaty on the Functioning of the European Union, HSPG/22-2009, p. 1.

${ }^{41}$ M. Sanchez-Aranzamendi, "European Commission Communication "Towards a space strategy for the European Union that benefits its citizens" - Towards a Lisbon Generation Competence, ESPI Perspectives 46, May 2011, p. 1.

${ }^{42}$ F. Mazurelle, J. Wouters and W. Thiebaut, "The Evolution of European Space Governance: Policy, Legal and Institutional Implications" International Organizations Law Review, 6 (2009) pp. 29-30.

${ }^{43}$ Information note: Article 189 of the Treaty on the Functioning of the European Union, HSPG/22-2009, p. 2.

${ }^{44}$ Cf. supra at note 36 .

${ }^{45}$ Information note: Article 189 of the Treaty on the Functioning of the European Union, HSPG/22-2009, p. 2.
} 


\section{Respective roles of EU, ESA and their Member States}

A second complicating factor in European space governance has been the so-called governance triangle, which has seen member states, the EU and ESA in various cooperative entanglements. Presently, 19 EU member states are also member states of ESA and several have national space agencies and space programmes as well. This is notably the case of France, Germany, Italy and the UK. ESA, which can trace its roots back to the fledgling attempts at European intergovernmentalism in space and to its predecessor organisations ESRO and ELDO in the 1960s, was conceived from the outset to coexist with and coordinate between national space efforts as well as to supplement them with a layer of intergovernmental programmes. As a new actor in space, the EU is thus faced with a crowded landscape consisting of a plethora of national and intergovernmental programmes. The formulation of the shared competence in Article 4(3) TFEU is to be seen in this light as well: it was the express wish of the drafters of the Treaty of Lisbon to safeguard the existing venues and mechanisms for intergovernmental cooperation in space. ${ }^{46}$

Between ESA and the EU, it proved necessary to formalise cooperation even before the EU gained a formal space competence. The Framework Agreement, which governs ESA-EU relations to this day, was adopted in 2003, entered into force in 2004 and has since been automatically renewed twice. Pursuant to this agreement, a Space Council was set up, which takes the form of joint and concomitant meetings of the Competitiveness Council of the EU and the ESA Council at ministerial level. Since 2004 it has met - albeit irregularly and with decreasing frequency - with the aim of coordinating and facilitating cooperative activities. ${ }^{47}$ Its output takes the form of resolutions, which however still have to be adopted separately by each organisation according to its own decision-making rules. Most notably, it has adopted a Resolution on the European Space Policy in $2007 .^{48}$

The EU's new space competence in Article 189 TFEU does not in itself affect the governance mechanisms put in place by the Framework Agreement. However, the vagueness of the "any appropriate relations" phrase, mentioned in Article 189(3), is such that it seems clear that the drafters of the Treaty of Lisbon did not want to predetermine the future mode of cooperation between the EU and ESA. The present Framework Agreement is therefore not an end point for European space governance; further indications of the EU's intentions to this effect can also be found in the most recent European Commission documents. ${ }^{49}$

\footnotetext{
${ }^{46}$ See F. Mazurelle, J. Wouters and W. Thiebaut, "The Evolution of European Space Governance: Policy, Legal and Institutional Implications" International Organizations Law Review, 6 (2009) p. 27.

47 Art. 8, Framework Agreement between the European Community and the European Space Agency, CE/ESA/en, pp. 12-13.

${ }^{48}$ Council Resolution on the European Space Policy, 22 May 2007, Council Doc. 10037/07.

${ }^{49}$ Communication from the Commission: "Towards a space strategy for the European Union that benefits its citizens", 11 Apr. 2011, $\operatorname{COM}(2011)$ 152, p. 12; Communication from the Commission: "Establishing appropriate relations between the EU and the European Space Agency", COM(2012) 671; Report from the Commission: "Progress Report on establishing appropriate relations between the European Union and the European Space Agency (ESA)", 6 Feb. 2014, Com(2014) 56 final.
} 
Making sense of the European institutional space puzzle rests in large part on the accurate interpretation of the hints given by the EU as to how it conceives of its own position in this landscape. First, the EU rightly recognizes and seeks to benefit from ESA's expertise at the technologic and scientific level, as well as in the management of space programmes and in its tradition of international cooperation in Europe. ${ }^{50}$ Second, whereas ESA is thus eminently well placed to supply space infrastructure and technology, the EU sees its role in aggregating societal demand for such capacities between itself, ESA and the member states. ${ }^{51}$ Likewise, the 2003 Framework Agreement is explicitly positioned as a strategic link between these two sides of the 'space market'. ${ }^{2}$ Third, drawing on its enlarged and formalised space mandate in Article 189 TFEU, the EU has stressed on the one hand the political dimension of space activities and on the other hand its legitimacy as an actor in these debates. ${ }^{53}$

On its part, ESA and its member states insist on keeping ESA as an independent space organization that would act as the "long-term partner of choice for the EU". ${ }^{4}$ In its most recent Ministerial Council meeting, ESA invites its Director General to review the European space policy with a view to submitting, by the end of 2015, "a jointly-elaborated European Space Policy and Long-Term space plan aimed at enhancing the benefits derived from the use of space infrastructure for the purpose of implementing sectorial policies in the EU and Member States", all the while continuing the dialogue with the European Commission. ${ }^{55}$

\section{EU measures on space debris}

Although clear mentions of potential activities in the field of space debris regulation are scarce in EU space policy documents, the EU has expressed concern with the sustainability of space activities in a variety of ways. First, under the heading of space and security, the EU Council has hinted at the potential use of space capabilities in pursuit of terrestrial security objectives ('space for security') in the framework of the Union's post-Lisbon competences in security and defence matters, as well as the need to protect space assets - and the economic interests they represent - from adverse outside influence ('security for space'). ${ }^{56}$ To this end, a space situational awareness (SSA) programme was commissioned by the ESA Ministerial Council in

\footnotetext{
${ }^{50}$ Communication from the Commission: "Towards a space strategy for the European Union that benefits its citizens", 11 Apr. 2011, COM(2011) 152, p. 4.

${ }^{51}$ Council Resolution "Taking forward the European Space Policy", 26 September 2008, Council Doc. 13569/08, p. 4.

52 Art. 1(2)(d), Framework Agreement between the European Community and the European Space Agency, CE/ESA/en, p. 5.

${ }^{53}$ Communication from the Commission: "Towards a space strategy for the European Union that benefits its citizens", 11 Apr. 2011, $\operatorname{COM}(2011)$ 152, p. 12; Communication from the Commission: "Establishing appropriate relations between the EU and the European Space Agency", COM(2012) 671, p. 4; Report from the Commission: "Progress Report on establishing appropriate relations between the European Union and the European Space Agency (ESA)", 6 Feb. 2014, Com(2014) 56 final, p. 5.

${ }^{54}$ Resolution on ESA evolution, 2 December 2014, ESA/C-M/CCXLVII/Res. 3, para. 14.

55 Ibid., para. 15.

56 Council Resolution on Global challenges: taking full benefit of European space systems, 25 November 2010 , Council Doc. 16864/10, pp. 8-9; Communication from the Commission, Towards a space strategy for the European Union that benefits its citizens, 11 April 2011, $\operatorname{COM}(2011)$ 152, pp. 5-7; Council Resolution on Orientations concerning added value and benefits of space for the security of European citizens, 6 December 2011, Council Doc. 18232/11, para. 25; European Parliament Resolution on a space strategy for the European Union that benefits its citizens, 19 January 2012, 2011/2148, para. 35.
} 
close cooperation with the EU, the European Defence Agency (EDA) and the three organisations' respective member states.

Second, although none of the documents discussed here is outspoken on its applicability to space debris mitigation, let alone remediation, the preliminary paragraphs of the 2007 Resolution on the European Space Policy and the subsequent Space Council Resolution Taking forward the European Space Policy (adopted in 2008) do expressly 'emphasize' that "all of Europe's space activities contribute to the goals and fully respect the principles set out by the UN OST" and "that Europe supports the on-going efforts of the UN COPUOS on the mitigation and prevention of space debris". ${ }^{57}$ At the time, the UN COPUOS was in the process of adopting the guidelines and these references should therefore be read as explicit support for these guidelines. Moreover, the manifold references in the EU documents on outer space to 'an open and reliable access to space' and security in space imply a close connection with space debris that for all its vagueness allows a very general approach that includes not only mitigation but also remediation.

In recent years, EU regulation on space surveillance has become more focused, and with it the attention devoted to the hazards of space debris. Most importantly, the European Parliament and Council adopted, in 2014, a Decision establishing a Framework for Surveillance and Tracking Support. ${ }^{58}$ The Decision has the overarching goal of "ensuring the long-term availability of European and national space infrastructure, facilities and services which are essential for the safety and security of the economies, societies and citizens in Europe". ${ }^{59}$ Despite referring to the need to undertake initiatives with respect to the active removal of space debris $^{60}$, the main body text of the Decision refrains from any measures or obligations relating to debris remediation. Specifically, the Decision only aims at "surveying uncontrolled re-entries of spacecraft or space debris into the Earth's atmosphere and providing more accurate and efficient early warnings with the aim of reducing the potential risks to the safety of Union citizens and mitigating potential damage to terrestrial infrastructure; [and] seeking to prevent the proliferation of space debris". 61

\section{Draft Code of Conduct}

While the joint EU/ESA European Space Policy largely ignores the space debris problem and EU measures tend to deal with it only tangentially through the lens of space security, the issue is tackled head-on in the Union's own draft Code of Conduct for Outer Space Activities. ${ }^{62}$ A revised version of the original 2008 draft Code was adopted by the Council of the European Union in 2010. The document has been revised several times more since, most recently on 31

\footnotetext{
${ }^{57}$ Council Resolution on the European Space Policy, 22 May 2007, Council Doc. 10037/07, p. 3; Council Resolution, Taking forward the European Space Policy, 26 September 2008, Council Doc. 13569/08, p. 4.

58 Decision No. 541/2014/EU of the European Parliament and of the Council of 16 April 2014 establishing a Framework for Space Surveillance and Tracking Support, OJ L 158/227 of 27 May 2014.

59 Ibid., Art. 3 (1).

60 Ibid., pp. 6.

61 Ibid., Art. 3 (2).

62 Revised Code of Conduct for Outer Space Activities, annex to the Council Conclusions concerning the revised draft Code of Conduct for Outer Space Activities, Council Doc. 14455/10 of 11 October 2010.
} 
March 2014. ${ }^{63}$ The language of the Code is revealing for the role the EU has carved out for itself in the global struggle against space debris, amidst the plethora of other European and international actors in this field. The preamble of the Code notes that it was devised as a "set of best practices aimed at ensuring security in outer space", which could become "a useful complement to international space law" ${ }^{64}$ The Code is essentially a set of transparency and confidence-building measures intended to complement international rules, which is understandable in the light of the development of space debris rules in general. It also dovetails with the limitations of the Lisbon Treaty. At the same time, the approach taken by the Code aims to maximize what little competences have been conferred upon the EU under the TFEU.

The Code has been expressly endorsed by the Council as the basis for establishing broad consultations with major spacefaring nations outside the EU through its High Representative for Foreign Affairs and Security Policy, so as to revamp it as a veritable International Code of Conduct. ${ }^{65}$ In all, three rounds of multilateral open-ended consultations have been held between May 2013 and May 2014, all aimed at ensuring that the text of the Code, while having European roots, is acceptable to the greatest number of states. Despite these efforts, the adoption of the Code has met with continuing opposition from countries such as China and India ${ }^{66}$, while in talks with other major partners such as the United States, the Code has never met with anything more than a lukewarm reception. ${ }^{67}$ Whatever the prospects of the present document, the 'creeping' approach is a telling example of how the EU can use a restricted 'regional' competence to push for comprehensive global rules on space. In the meantime, the Council has never ceased to express its continuing support for the Code of Conduct, emphasizing in the process the relevance of the document for space debris purposes. ${ }^{68}$

While essentially the product of an intra-EU political process, the draft Code of Conduct is intended to provide a sound basis for the development of a veritable global code for outer space activities. In this context, the focus of the present draft Code on the issue of space debris - be it or not via the broader notion of space security - bears promising potential. The draft Code's pertinence for space debris is apparent throughout the entire document and reveals itself already in the main goals set out in the preamble and first provisions of the instrument. After noting that space debris "affects the sustainable use of outer space, constitutes a hazard to outer space activities and potentially limits the effective deployment and utilisation of associated space capabilities" (PP 8), the draft Code puts forward the freedom of access to space for

\footnotetext{
63 Version available at http://www.eeas.europa.eu/non-proliferation-anddisarmament/pdf/space code conduct draft vers 31-march-2014 en.pdf (accessed on 23 February 2015).

64 Ibid., p. 4.

${ }^{65}$ Council Decision 2012/281/CFSP of 29 May 2012 in the framework of the European Security Strategy in support of the Union proposal for an international Code of Conduct on outer-space activities, OJ L 140/68 of 30 May 2012.

${ }^{66}$ See, for instance, M. Listner, "EU Code of Conduct: commentary on Indian concerns and their effects", The Space Review, 28 November 2011, available at http://www.thespacereview.com/article/1977/1 (accessed on 23 February 2015). See also http://nationalspacestudiescenter.wordpress.com/2011/11/30/what-india-hates-about-the-spacecode-of-conduct/ (accessed on 23 February 2015).

${ }^{67}$ See the latest statement on the issue in the address of F.A. Rose, "State Department: leading with diplomacy to strengthen stability in space", 17 November 2011, available at http://www.state.gov/t/avc/rls/177306.htm (accessed on 23 February 2015).

${ }^{68}$ See, most recently, Council Decision (CFSP) 2015/203 of 9 February 2015 in support of the Union proposal for an international Code of Conduct for outer-space activities as a contribution to transparency and confidence-building measures in outer-space activities, OJ L 33/38 of 10 February 2015.
} 
peaceful purposes and the preservation of the security and integrity of space objects in orbit two of the fundamental principles of a comprehensive approach to outer space activities (Art. 2).

The appositeness of these principles for the diminution of the space debris population is concretized in a separate section on 'Measures on outer space operations and space debris mitigation'. In this section, Article 4 notes that '[t]he Subscribing States resolve to establish and implement policies and procedures to minimise the risk of accidents in space, collisions between space objects, or any form of harmful interference with another State's peaceful exploration, and use, of outer space" (Art. 4.1).

To this end, States are encouraged to "take appropriate measures to minimize the risk of collision, and to refrain from any action that brings about, directly or indirectly, damage, or destruction, of space objects unless such action is justified [...] in order to reduce the creation of space debris [...] and where such exceptional action is necessary, that it be undertaken in a manner so as to minimise, to the greatest extent practicable, the creation of space debris" (Art. 4.2). The article continues to identify two main means of limiting space debris. In conducting outer space activities, the subscribing States should, first, "limit, to the greatest extent practicable, any activities in the conduct of routine space operations, including during the launch and the entire orbital lifetime of a space object, which may generate long-lived space debris", and, second, "adopt and implement, in accordance with their own internal processes, the appropriate policies and procedures or other effective measures in order to implement the Space Debris Mitigation Guidelines of the [UN COPUOS] as endorsed by [UNGA] Resolution 62/217" (Art. 4.3 and 4.4).

The general nature of the measures on combating space debris proposed in the draft Code, combined with the global aspirations expressed by the Council and EU High Representative, could well make the draft Code of Conduct for Outer Space Activities an appropriate starting point for developing stronger international rules on space debris. In particular, the call on subscribing States to refrain from any destruction of space objects unless such action itself is taken to reduce the creation of space debris, may be read as a much-needed reference to active debris removal. However, the document's reticence, when listing the means of limiting space debris, to go beyond the recommendation of mere mitigation measures militates against any hope one might hold for a progressive take on debris remediation in the Code of Conduct.

The manifold references to the existing body of international rules on debris mitigation and international space law in general cast severe doubt on the self-proclaimed aspirations of the EU to act as a global player in the field of the space environment. ${ }^{69}$ As a result, even if the Code of Conduct could gain the acceptance of all major spacefaring nations - which is highly doubtful given the recalcitrance of certain key partners, yet pivotal if Europe is serious about addressing a universal problem such as space environment and security - it remains to be seen what the effect of this instrument will be and, most importantly for present purposes, whether it will have

\footnotetext{
${ }^{69}$ See also the 21 October 2009 address by the EU Presidency to the Fourth Committee of the UNGA on Peaceful uses of outer space, available at http://eu-un.europa.eu/articles/en/article 9132 en.htm (accessed on 10 March 2015).
} 
any added value over and above the parallel path taken by the EU/ESA member states through their space agencies.

\section{ConcLusion}

Over the past decades, national and regional space agencies in Europe have adopted an elaborate body of rules aimed at tackling the crucial problem of debris in outer space. Much like their international counterparts, however, these rules have mainly focused on mitigating the degradation of the space environment by proscribing the creation of new pieces of refuse. Regardless, the policy framework on space debris in which these European players operate is sufficiently broad as to allow for the adoption of forceful rules promoting active debris remediation as well. In terms of legal process, the constant interaction between the European space agencies and other actors at the national, regional and international levels has demonstrated a flexibility in the evolution of mitigation rules that may well be replicated for debris remediation norms, provided the political willingness of those involved is strong enough to overcome the formidable economic objections to such undertakings. The recuperation of nonbinding international guidelines developed with the cooperation of ESA and the four main national space agencies on the European continent into binding legal prescriptions by various EU member states is telling in this respect.

In light of this particular legal process, some caution may be expressed regarding the debris remediation role of the EU, which, even according to its own space policy, is still only one of the many players that should develop Europe as a leading space power on the international scene. At the same time, the direct implementation by individual EUMS of international rules adopted in close cooperation with the European space agencies and space industry, risks further diminishing the regulatory space carefully carved out for the middle-level player that is the EU in the Lisbon Treaty. Still, it is beyond doubt that the EU is the only one of all the designated European actors in space that carries sufficient political weight to effectively further the European cause on the international scene. Moreover, we have seen that the narrow legal base of Article 189 TFEU can be complemented on other fronts, and does not preclude the Union from guiding regulatory convergence for space remediation rules through recommendations and best practices. Whether or not the draft Code of Conduct for Outer Space Activities will really mark the start of a universal codification of active debris remediation measures, it is clear that the regulatory initiatives of the European space agencies should be buttressed by firm political action at the level of the EU. 


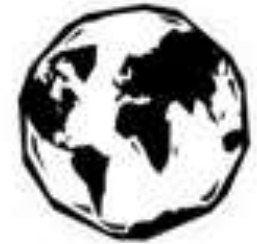

Institute for International Law

The Leuven Centre for Global Governance Studies is an interdisciplinary research centre of the Humanities and Social Sciences recognized as a Centre of Excellence at the KU Leuven. It hosts researchers from law, economics, political science, history, philosophy and area studies. The Centre initiates and conducts interdisciplinary research on topics related to globalization, governance processes and multilateralism, with a particular focus on the following areas: (i) the European Union and global governance; (ii) human rights, democracy and rule of law; (iii) trade and sustainable development; (iv) peace and security; (v) global commons and outer space; (vi) federalism and multi-level governance; (vii) non-state actors and emerging powers. It hosts the InBev Baillet-Latour Chair EU-China and the Leuven India Focus.

In addition to its fundamental research activities the Centre carries out independent applied research and offers innovative policy advice and solutions to policy-makers.

In full recognition of the complex issues involved, the Centre approaches global governance from a multi-level and multi-actor perspective. The multi-level governance perspective takes the interactions between the various levels of governance (international, European, national, subnational, local) into account, with a particular emphasis on the multifaceted interactions between the United Nations System, the World Trade Organization, the European Union and other regional organizations/actors in global multilateral governance. The multi-actors perspective pertains to the roles and interactions of various actors at different governance levels, which includes public authorities, formal and informal international institutions, business enterprises and non-governmental organizations.

For more information, please visit the website www.globalgovernancestudies.eu

Leuven Centre for Global Governance Studies

Huis De Dorlodot, Deberiotstraat 34, 3000 Leuven, Belgium

Tel. ++32 16328725

Fax ++32 16373547

info@ggs.kuleuven.be

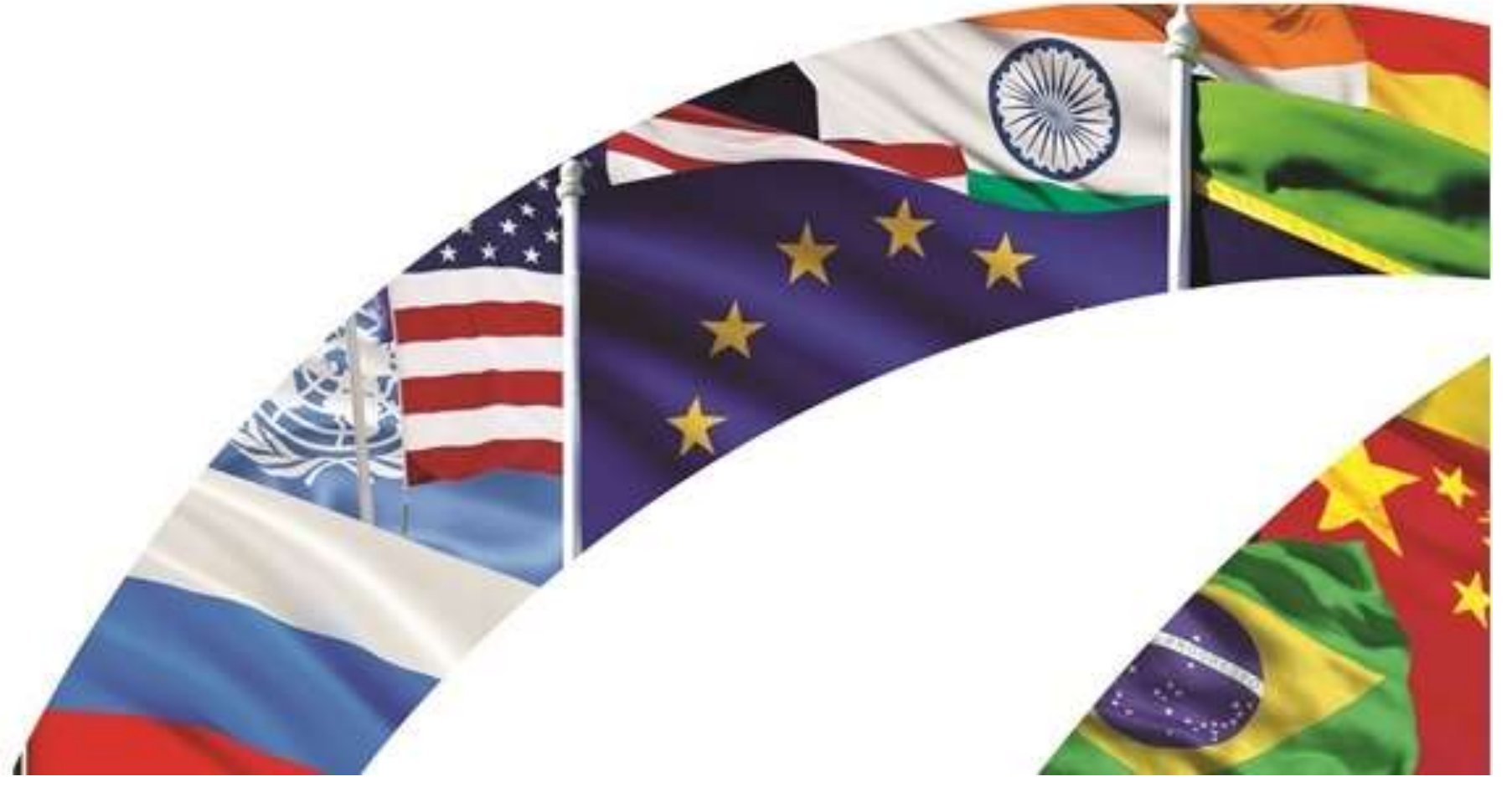

